\section{Multi-environment Selection of Small Sieve Snap Beans Reduces Production Constraints in East Africa and Subtropical Regions}

\author{
Charles J. Wasonga \\ Department of Horticultural Sciences, Cornell University NYSAES, 315 \\ Hedrick Hall, Geneva, NY 14456
}

\author{
Marcial A. Pastor-Corrales \\ U.S. Department of Agriculture, Agricultural Research Service, Beltsville \\ Agricultural Research Center, Beltsville, MD 20705
}

Timothy G. Porch

U.S. Department of Agriculture, Agricultural Research Service, Tropical Agriculture Research Station, Mayagüez, PR 00680

Phillip D. Griffiths ${ }^{1}$

Department of Horticultural Sciences, Cornell University NYSAES, 315 Hedrick Hall, Geneva, NY 14456

Additional index words. breeding, common bean rust, high temperature stress, Phaseolus vulgaris income for smallholder farmers in East Africa. In this region as well as in other tropical and subtropical environments, common bean rust, caused by Uromyces appendiculatus (Pers.:Pers.), and heat stress reduce the yield and quality of snap beans. Small-sieve rustresistant snap beans and that are heat-tolerant were developed using heat-tolerant snap bean breeding lines that had broad-spectrum rust resistance conditioned by the combination of the Andean $U r-4$ and Mesoamerican $U r-11$ genes. The $U r-4$ and $U r-11$ rust gene combination confers resistance to 90 races of the hypervariable pathogen from different parts of the world, including East Africa, that are maintained at Beltsville, MD. Four breeding lines each having the combination of the two rust genes were crossed in a $4 \times 5$ diallel mating design with five susceptible small-sieve cultivars to give $20 \mathrm{~F}_{1}$ hybrids. The hybrid combinations were advanced through the $F_{2}, F_{3}$, and $F_{4}$ generations with selection for heat tolerance, rust resistance, and pod quality to develop lines combining these traits. Twenty $F_{5}$ breeding lines that had the combination of these traits were selected and evaluated in East Africa at four field sites selected on the basis of differences in altitude, climate, and virulence diversity of the bean rust pathogen and in Puerto Rico at a field site characterized by high temperatures. There was a significant positive correlation between ranks of heat stress influenced yield components (seeds per pod and total yield) at the hot field site and the controlled high-temperature $\left(32 / 27^{\circ} \mathrm{C}\right)$ greenhouse. Four of the breeding lines developed, L5, L9, L13, and L17, combined heat tolerance and rust resistance in the desired plant type with high yield and good pod quality. These lines are the first known small-sieve snap beans with the combination of traits for heat tolerance and broadspectrum rust resistance conferred by the $U r-4$ and $U r-11$ genes. These results demonstrate ability to combine heat tolerance and rust resistance as important traits for adaptation of specific market classes of common bean to tropical and subtropical environments through targeted selection of multiple traits in controlled environments.

Snap beans or green beans have been selected for high pod quality with reduced fiber and are consumed as green pods harvested for the fresh market or processing. Slender or "small-sieve" snap beans or green beans, also known as "French beans" are an important source of income for smallholder growers in East Africa who produce the crop for export markets typically in Western Europe [CBI, 2006; Centro Internacional de Agricultura Tropical (CIAT), 2006; Muchui et al., 2008; Okello and Roy, 2007], but they are also increasingly becoming important for domestic markets where they provide an important
Wortmann et al., 1998). Rust is a destructive disease of common beans in subtropical and tropical regions and is particularly severe in eastern and southern Africa (Kimani et al., 2002; Liebenberg et al., 2006; Wortmann et al., 1998). Heat stress and rust occur within the same production regions in East Africa (Wasonga et al., 2010) reducing both the quality and yields of snap bean crops generated.

The majority of snap bean cultivars grown in East Africa are highly susceptible to rust (Kimani et al., 2002; Wasonga et al., 2010). Use of genetic resistance in the management of bean rust has been difficult to achieve as a result of the extensive and shifting nature of virulence diversity of the pathogen (Araya et al., 2004; Liebenberg, 2003; Markell et al., 2009; Wright et al., 2008) coupled with lack of a single resistance gene that could confer resistance against all the races of the pathogen (Pastor-Corrales, 2006; Stavely and PastorCorrales, 1989). The deployment of Andean $U r-4$ in combination with Middle American $U r-11$ rust-resistance genes provided effective resistance to rust at different test sites in East Africa (Wasonga et al., 2010)

Higher than optimal temperatures (heat stress) adversely affect crop growth and productivity (Challinor et al., 2007; Wahid et al., 2007). Snap bean production in East Africa is currently limited to cool highland areas above $1500 \mathrm{~m}$, because higher night temperatures experienced at lower altitudes reduce yield and green pod quality. Furthermore, land areas that are suitable for snap bean production in the East Africa region are expected to reduce in size given climate change-associated temperature increases currently being experienced across sub-Saharan Africa (Hulme et al., 2001; King'uyu et al., 2000). These temperature increases in subSaharan Africa are expected to exceed projected global mean increase of $2.5^{\circ} \mathrm{C}$ by 0.7 to $1.1{ }^{\circ} \mathrm{C}$ by the end of the 21 st century (Christensen et al., 2007; Cline, 2007). There is therefore need to adopt crop-specific production approaches that would enable increased or sustained productivity under elevated temperature conditions.

Genetic improvement of snap bean for tolerance to high-temperature stress is a promising option for increasing yield and quality in heat-stressed environments (Porch and Jahn, 2001; Rainey and Griffiths, 2005). Wasonga et al. (2010) developed and tested in East Africa some heat-tolerant snap bean breeding lines that demonstrated potential for improving production in the region as well as other tropical and subtropical environments where high temperatures presently limit production and changing climatic conditions are likely to become more challenging.

Among the quality attributes used to categorize snap beans for East Africa production are a small pod diameter, commonly referred to as small-sieve, in a long, slender, dark green pod. Size is determined by the maximum width of the pod measured at right angles to the seam and is classified as follows: 1) extra fine: width of the pod not exceeding $6 \mathrm{~mm}$ (sieve size 1); 2) fine: width of the pod 
not exceeding $9 \mathrm{~mm}$ (sieve sizes 2 and 3); and 3) medium: width of the pod not exceeding $12 \mathrm{~mm}$. In East Africa, small-sieve snap bean cultivars producing extrafine and fine pods are the grades that growers desire for the markets served (Muchui et al., 2008). The small-sieve snap bean cultivars currently grown in East Africa lack the optimal combinations of traits for more efficient production that would be provided by incorporation of rust resistance and tolerance to high-temperature stress.

The overall goal was to improve snap bean for rust resistance and heat tolerance to increase production in environments experiencing these challenges need to ensure that the optimal traits are combined in desired market types that are high-yielding with good pod quality. The specific objectives of this study were to: 1) combine heat tolerance and optimal rust-resistance gene combinations in small-sieve snap bean genotypes; and 2) evaluate the snap bean lines in five locations in East Africa and one site in Puerto Rico, which differ in climatic conditions and virulence diversity for the bean rust pathogen.

\section{Materials and Methods}

\section{Population development}

Four parental snap bean breeding lines (HT1, HT2, HT3, and HS1) whose pedigrees are detailed in Wasonga et al. (2010) were used as sources for high-temperature tolerance and broad-spectrum rust resistance involving the $U r-4$ and $U r-11$ rust-resistance genes. HT1, HT2, and HT3 each had the combination of the traits for high-temperature tolerance and the two rust-resistance genes. HS1 had the $U r$ 4 and $U r-11$ rust genes but lacked the trait for high-temperature tolerance and was included to enable the development of lines with low tolerance to high temperatures to be used as checks. The four lines were planted on 23 June 2008 and crossed in a $4 \times 5$ diallel mating design to five selected snap bean cultivars: 'Amy' (Seminis, St. Louis, MO), 'Teresa' (Seminis), and 'PV712' (Pop Vriend, Andijk, The Netherlands), which are currently grown in or targeted for production in East Africa but lack tolerance to high temperatures and/or effective rust resistance, and 'Masai' (Syngenta, Boise, ID) and 'Bronco' (Seminis), which are grown in the United States. 'PV712' is a new

Received for publication 22 Mar. 2012. Accepted for publication 12 June 2012.

We acknowledge with appreciation financial support for this study from the Cornell Assistantship for Horticulture in Africa (CAHA), Alliance for Green Revolution in Africa (AGRA), Towards Sustainability Fund (TSF), the Bradfield Research Award, and the Einaudi International Research Travel Grant of Cornell University. The excellent field support provided by KARI (Kenya Agricultural Research Institute)-Kitale and Kakamega Regional Research Centers, Homabay Farmers Training Center in Kenya, and the AVRDC World Vegetable Center-Regional Center for Africa in Arusha, Tanzania, is highly appreciated.

${ }^{1}$ To whom reprint requests should be addressed; e-mailpdg8@cornell.edu. genotype targeted for East Africa that has the $U r-4$ and $U r-11$ rust-resistance gene combination but is highly sensitive to high temperatures (Wasonga et al., 2010). 'Teresa' has the $U r-5$ rust-resistance gene but is also sensitive to high temperatures. 'Amy' is susceptible to the bean rust pathogen and also sensitive to heat stress. 'Masai' is a rust-susceptible and heatsensitive cultivar grown for the small-sieve "whole bean" market in the United States and 'Bronco' is a fresh-market medium-sieve snap bean cultivar with some tolerance to higher temperatures but susceptible to rust (Wasonga et al., 2010). The parents were grown in a greenhouse with temperatures set at $24 / 21{ }^{\circ} \mathrm{C}$ (day/night) and crosses made through handpollination in a $4 \times 5$ diallel mating design.

\section{Breeding line selection}

The $20 \mathrm{~F}_{1}$ hybrid combinations from crosses involving the four snap bean breeding lines and five snap bean cultivars were generated in July 2008 (Fig. 1). $F_{1}$ phenotypes were visually compared with phenotypes of the corresponding parents to validate successful crosses from which the $F_{1}$ hybrids were selected. The selected $F_{1}$ hybrid seed were allowed to self-pollinate under greenhouse environment, $24 / 21{ }^{\circ} \mathrm{C}$ (day/night, 14-h photoperiod), in Geneva, NY, to produce $20 \mathrm{~F}_{2}$ populations (Fig. 1). In Jan. 2009, 40 plants from each of the $20 \mathrm{~F}_{2}$ populations were grown in the same greenhouse environment with similar environmental conditions as described previously. Single plants were grown in $20-\mathrm{cm}$ diameter and $20-\mathrm{cm}$ deep round plastic pots filled with "Cornell mix" growth medium (Boodley and Sheldrake, 1972). The pots were arranged in a randomized complete block design (RCBD) with four replications with each block/replicate having 10 plants of each of the $20 \mathrm{~F}_{2}$ populations. The RCBD arrangement was adopted so to take care of possible temperature variability that could arise from uneven airflow within the greenhouse. The $\mathrm{F}_{2}$ populations were evaluated and a stratified selection approach followed to pick the best four individual plants from each $\mathrm{F}_{2}$ population on the basis of yield, small-sieve pods and small seed size. A total of 80 selections were made, representing four lines from each of the 20 possible cross combinations.

The 80 selected $\mathrm{F}_{3}$ and nine parental lines were planted in a greenhouse in Apr. 2009 for selection for tolerance to high temperatures, pod quality, and pod size among other phenotypic evaluations (Fig. 1) followed by selection based on yield components. During the evaluation of the $\mathrm{F}_{3}$ generation, temperatures in the greenhouse were $24 / 21{ }^{\circ} \mathrm{C}$ (day/ night) for the first 3 weeks after planting and then adjusted to $32 / 27{ }^{\circ} \mathrm{C}$ (day/night) before the onset of anthesis. The high-temperature environment was maintained until plants ceased flower set.

Five yield components were documented: number of pods per plant, number of seeds per plant, number of seeds per pod, total seed weight per plant, and mean seed weight (calculated from 100-seed weight) and used for the selection of the most promising lines, maintaining representation from all lineages. The best plants were identified from each of the $80 \mathrm{~F}_{3}$ lines based on rankings of seed size,

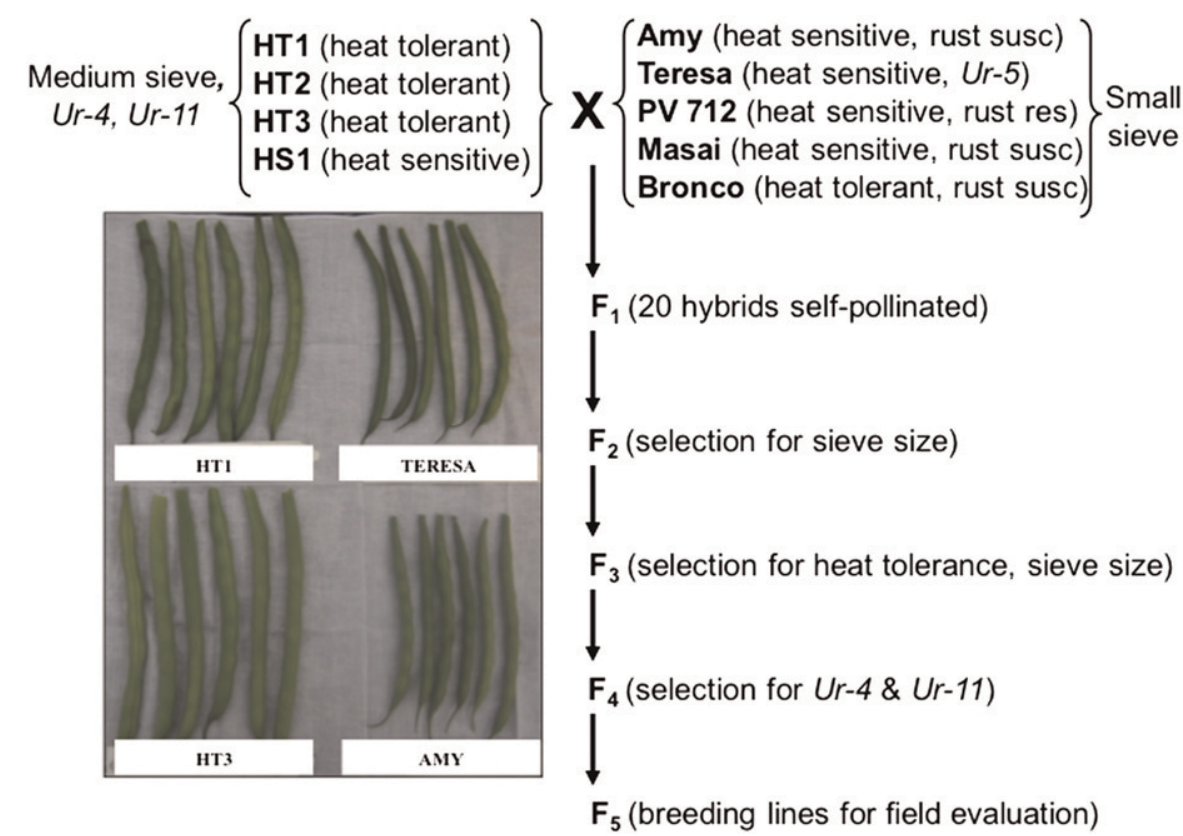

Fig. 1. Breeding scheme for the development, evaluation, and selection of rust-resistant heat-tolerant snap beans with small-sieve pod quality attributes for East Africa. Some of the key characteristics of the parents used are shown in brackets. Inset is a picture illustrating differences in pod sieve sizes between lines used in the crosses. Sieve size is a pod quality attribute that refers to the size of pods as determined by the maximum width of the pod measured at right angles to the seam. It is classified as follows: 1) extrafine: width of the pod not exceeding $6 \mathrm{~mm}$ (sieve size 1);2) fine: width of the pod not exceeding $9 \mathrm{~mm}$ (sieve sizes 2 and 3); and 3) medium: width of the pod not exceeding $12 \mathrm{~mm}$. Lines with pods not exceeding $9 \mathrm{~mm}$ are considered small sieve and are usually small-seeded. 
the mean number of seeds per pod, and the total seed yield under high-temperature stress. The 80 selected $\mathrm{F}_{3}$ lines were concurrently tested for the presence of $U r-4$ and $U r-11$ rustresistance genes to identify lines fixed for the two genes and the lines were also increased for seed. The procedure followed for identifying plants with the presence of the $U r-4$ and $U r-11$ rust-resistance genes under greenhouse conditions at the USDA-ARS-BARC facilities is described in detail in Wasonga et al. (2010). The $\mathrm{F}_{4}$ lines, which were presumably fixed for the $U r-4$ and $U r-11$ rust-resistance genes, were identified. For each of the 20 lineages, four lines that were preliminarily determined to be fixed for the two rust-resistance genes and also ranked high in heat tolerance were selected. Heat-tolerant lines that were fixed or heterozygous for the $U r-11$ gene were selected in situations in which less than four lines were fixed for the two rust-resistance genes in that lineage. This was undertaken to ensure equal lineage representation during subsequent field evaluation and selection; this resulted in 20 lines being selected for evaluation at the East African sites (Table 1). Four plants of each of the 20 lines were grown under greenhouse conditions with temperatures of 24/21 ${ }^{\circ} \mathrm{C}$ (day/night, 14-h photoperiod) for seed increase.

\section{Field and greenhouse evaluation of breeding lines}

Plant material and trial design. The $20 \mathrm{~F}_{5}$ small-sieve snap bean breeding lines were increased and evaluated for reaction to rust and yield components in a high-temperature greenhouse adjusted to $32 / 27^{\circ} \mathrm{C}$ (day/night), in Geneva, NY, and under field conditions at four sites in East Africa and one in Puerto Rico together with the donor parents HT1, HT2, HT3, and HS1 and cultivar parents Amy, PV 712, Teresa, Masai, and Bronco as checks. Other cultivars adapted for production in other geographical regions and previously tested under field conditions in East Africa (Wasonga et al., 2010) were included as additional checks during the field evaluation, including: 'PV 698' (Pop Vriend) developed for East Africa; 'Barrier' and 'Juliet' (Alpha Seeds, Henley on Klip, South Africa) developed for Southern Africa; 'Palati' (Syngenta, Boise, ID) developed for Northern Africa; 'Opus' and 'Brio' (Seminis) developed for the southeast United States; and 'Hystyle' (Harris Moran, Modesto, CA) developed for northeast United States. There were 36 entries in total for the field performance trials. The entries were grown in a RCBD with four replications per site at four field sites in East Africa and at one site in Puerto Rico (Homabay, Kenya; Kakemega, Kenya; Kitale, Kenya; Arusha, Tanzania; Juana Diaz, Puerto Rico). The lines were evaluated in a greenhouse with controlled temperatures at $32 / 27{ }^{\circ} \mathrm{C}$ (day/night) to determine correlations between controlled-temperature testing and field performance.

A set of 12 differential cultivars was also planted at four sites in East Africa with the aim of determining the virulence diversity/

Table 1. Pedigree, yield components, and rust-resistance gene status of 20 snap bean breeding lines grown for selection under greenhouse and field environments in $2010 .^{\mathrm{z}}$

\begin{tabular}{|c|c|c|c|c|c|c|c|}
\hline $\begin{array}{l}\text { Line } \\
\text { name }\end{array}$ & Pedigree & $\begin{array}{l}\text { Seeds/ } \\
\text { plant }\end{array}$ & $\begin{array}{l}\text { Pods/ } \\
\text { plant }\end{array}$ & $\begin{array}{l}\text { Seed wt } \\
(\mathrm{g} / \text { plant })\end{array}$ & $\begin{array}{l}\text { Seeds/ } \\
\text { pod }\end{array}$ & $\begin{array}{c}\text { Single seed } \\
\text { wt }(\mathrm{g})\end{array}$ & $\begin{array}{c}\text { Rust-resistance } \\
\text { genes }\end{array}$ \\
\hline$\overline{\mathrm{L} 1}{ }^{\mathrm{y}}$ & (HT2 * Amy) F3-4 P1 & 104 & 30 & 14.5 & 3.5 & 0.14 & $U r-4, U r-11$ \\
\hline $\mathrm{L} 2$ & (HT3 * Amy) F3-4 P1 & 104 & 47 & 22.6 & 2.2 & 0.22 & $U r-11$ \\
\hline $\mathrm{L}^{\mathrm{y}}$ & (HT3 * Amy) F3-4 P3 & 118 & 29 & 15.7 & 4.1 & 0.13 & $U r-11$ \\
\hline $\mathrm{L} 4^{\mathrm{y}}$ & (HT3 * Amy) F3-2 P4 & 170 & 47 & 24.9 & 3.6 & 0.15 & $U r-11$ \\
\hline L5 & $(\mathrm{HT} 1 *$ Bronco) $\mathrm{F} 3-1 \mathrm{P} 2$ & 95 & 30 & 15.2 & 3.2 & 0.16 & $U r-4, U r-11$ \\
\hline $\mathrm{L} 6^{\mathrm{y}}$ & (HT1 * Bronco) F3-4 P3 & 94 & 29 & 11.0 & 3.2 & 0.12 & $U r-4, U r-11$ \\
\hline $\mathrm{L}^{\mathrm{y}}$ & (HT3 * Bronco) F3-1 P3 & 103 & 33 & 17.6 & 3.1 & 0.17 & $U r-4, U r-11$ \\
\hline L8 & (HS1 * Bronco) F3-2 P3 & 81 & 28 & 17.4 & 2.9 & 0.21 & $U r-4, U r-11$ \\
\hline L9 & (HT1 * PV712) F3-2 P1 & 85 & 22 & 16.5 & 3.9 & 0.19 & $U r-4, U r-11$ \\
\hline L10 & (HT1 * PV712) F3-2 P2 & 93 & 24 & 13.9 & 3.9 & 0.15 & $U r-4, U r-11$ \\
\hline L11 & (HT3 * PV712) F3-3 P4 & 107 & 29 & 19.5 & 3.7 & 0.18 & $U r-4, U r-11$ \\
\hline $\mathrm{L} 12$ & (HT3 * PV712) F3-4 P3 & 95 & 34 & 13.4 & 2.8 & 0.14 & $U r-4, U r-11$ \\
\hline L13 & (HT1 * Masai) F3-2 P3 & 107 & 20 & 15.1 & 5.4 & 0.14 & $U r-4, U r-11$ \\
\hline $\mathrm{L} 14^{\mathrm{y}}$ & (HT1 * Masai) F3-4 P3 & 164 & 38 & 24.1 & 4.3 & 0.15 & $U r-4, U r-11$ \\
\hline L15 & (HT2 * Masai) F3-1 P4 & 145 & 41 & 19.5 & 3.5 & 0.13 & $U r-4, U r-11$ \\
\hline L16 & (HS1 * Masai) F3-2 P4 & 106 & 32 & 15.4 & 3.3 & 0.15 & $U r-4, U r-11$ \\
\hline L17 & (HT1 * Teresa) F3-1 P3 & 98 & 50 & 19.3 & 2.0 & 0.20 & $U r-4, U r-11$ \\
\hline L18 & (HT1 * Teresa) F3-4 P3 & 102 & 20 & 14.9 & 5.1 & 0.15 & $U r-11$ \\
\hline L19y & $(\mathrm{HT} 3 *$ Teresa) F3-2 P1 & 90 & 33 & 13.7 & 2.7 & 0.15 & $U r-4, U r-11$ \\
\hline$\underline{\mathrm{L} 20}$ & $(\mathrm{HS} 1 *$ Teresa) F3-4 P4 & 98 & 37 & 17.5 & 2.7 & 0.18 & $U r-4, U r-11$ \\
\hline
\end{tabular}

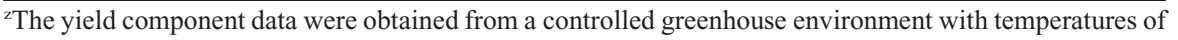
$24 / 21^{\circ} \mathrm{C}$ (day/night).

y These breeding lines were heterozygous for $U r-4$ and $U r-11$ rust-resistance genes.

spectrum of common bean rust isolates present at the field sites. Six of the differential cultivars (with their rust-resistance genes in parenthesis) were from the Andean gene pool and included 'Early Gallatin' (Ur-4), 'Redlands Pioneer' (Ur-13), 'Montcalm' (unknown rust-resistance genes), 'Pompadour Checa (PC) 50' (Ur-9, Ur-12), 'Golden Gate Wax' (Ur-6), and 'PI 260418' (unknown rust-resistance genes); whereas the cultivars from the Middle American gene pool included 'Great Northern 1140' (Ur-7), 'Aurora' (Ur-3), 'Mexico 309' (Ur-5), 'Mexico 235' (Ur-3+), 'Compuesto Negro Chimaltenango' (CNC; unknown rustresistance genes), and 'PI 181996' (Ur-11).

Field trial locations and descriptions. The field trials were carried out between March and June 2010 during the long rainy season at four sites in East Africa: Arusha in Tanzania (AVRDC-RCA), Homabay (at the Farmers Training Center), Kakamega and Kitale in Kenya (KARI sites), and between July and Sept. 2010 in Juana Diaz, Puerto Rico (University of Puerto Rico). The sites were selected on the basis of differences in soils, altitude, and climate as detailed in Wasonga et al. (2010). The altitude at the East African sites were $1235,1172,1585$, and $1829 \mathrm{~m}$ above sea level at Arusha, Homabay, Kakamega, and Kitale, respectively. Mean minimum and maximum temperatures, respectively, at the sites during the field trial period were: Arusha (13.0/ $\left.24.3^{\circ} \mathrm{C}\right)$, Homabay $\left(17.0 / 33.5^{\circ} \mathrm{C}\right)$, Kakamega $\left(15.5 / 28.9^{\circ} \mathrm{C}\right)$, Kitale $\left(13.6 / 25.7^{\circ} \mathrm{C}\right)$, and Puerto Rico $\left(23 / 35^{\circ} \mathrm{C}\right)$. The lowest and the highest mean temperatures were recorded at Arusha and Puerto Rico, respectively.

The field sites were tractor-plowed to a fine tilth before planting. Planting dates were 10 Mar. (Arusha), 22 Mar. (Kakamega), 24 Mar. (Kitale), 26 Mar. (Homabay), and 1 June (Puerto Rico). Single rows of 25 seeds were planted per block for each of the 36 entries. A planting density in which seeds were placed at $0.5 \mathrm{~m}$ between rows and $0.1 \mathrm{~m}$ within rows was used. A compound inorganic fertilizer $(10 \mathrm{~N}-11.3 \mathrm{P}-8.3 \mathrm{~K})$ was row-applied at planting at a rate of $200 \mathrm{~kg} \cdot \mathrm{ha}^{-1}$ at all African sites except Arusha whose soils were considered fertile. A compound inorganic fertilizer (10N-10P-10K) was applied in Puerto Rico at a rate of $400 \mathrm{~kg} \cdot \mathrm{ha}^{-1}$. The African trial plots were rain-fed but supplemental irrigation was applied to avert potential water stress resulting from low rainfall during the early stages of the trial. In Puerto Rico, drip irrigation was used to irrigate the plot. The plots were kept weed-free on a biweekly basis through hand cultivation starting soon after emergence.

\section{Data collection and analysis}

The snap bean entries and differential cultivars were monitored for symptoms of rust and the date on which the first disease symptoms were observed at each site was noted so as to enable accounting for possible site differences in rust severity and its effect on yield. During an earlier trial at these sites, it was observed that reduction in yield that was attributed to rust on susceptible genotypes was more pronounced when the disease manifested at a site earlier in the season compared with later in the season (Wasonga et al., 2010). A recording of the dates on which the disease was first observed at the sites enabled an accounting of site yield differences for specific genotypes, especially at sites where early- and late-season infections were observed.

The entries were scored for incidence and severity of the bean rust pathogen at flowering (R6) and at pod filling (R8) developmental stages. Quantitative information on line reaction to rust and rust incidence was obtained by counting the number of rust infected plants per plot, whereas rust severity was determined by the number of visible rust pustules $(0.5 \mathrm{~mm}$ 
or greater) formed per leaflet in each of the four replicates. Correlation analysis of rust incidence and severity was used to visualize line differences in reaction to rust. In the correlation plot, genotypes that had no rust were considered highly resistant, whereas those with high rust incidence and severity were considered highly rust-susceptible (Wasonga et al., 2010). The genotypes that had high, moderate, or low rust severity on a few plants (low incidence) were assumed to be either partially rust-resistant or heterozygous for the rust-resistance genes.

The performance of the lines for yield was obtained by recording the number of pods produced per plant at the field sites in East Africa. In the greenhouse trial in New York and the field trial in Puerto Rico, where the goal was to test response to heat stress, data were collected for seed weight per plant and seeds per pod because these are considered most indicative of response to hightemperature stress. The total number of pods produced per plot were counted while excluding single plants at the end of the rows and then divided by the total number of plants examined within the plot.

The statistical model used in the data analysis was:

$$
y_{i j k}=\mu+\alpha_{i}+\beta_{j}+\alpha \beta_{i j}+\varepsilon_{i j k}
$$

where: $\mathrm{y}_{\mathrm{ijk}}=\mathrm{k}^{\text {th }}$ response at combination $(\mathrm{i}, \mathrm{j})$; $\mu=$ overall mean; $\alpha_{i}=$ main effect of line $i ; \beta_{j}=$ main effect of site $\mathrm{j} ; \alpha \beta_{\mathrm{ij}}=$ line/site interaction effect; and $\varepsilon_{\mathrm{ijk}}=$ random error associated with $\mathrm{k}^{\text {th }}$ response at combination $(i, j)$. The main effect of line $\alpha_{i}$ was considered fixed, whereas the effect of site $\beta_{j}$ was considered random.

JMP 8 software (SAS Institute Inc., Cary, NC) was used to conduct analysis of variance for disease severity, pods per plant, seed weight per plant, and seeds per pod, and pairwise comparisons of means were made using Tukey's multiple means comparison method. Phenotypic correlation coefficients among the measured yield components in the greenhouse and field were calculated using Spearman's rank correlation. Information on rust resistance, pod yield, plant type, and pod quality was used to select superior lines.

\section{Results and Discussion}

\section{Reaction to common bean rust under field conditions}

There was higher virulence diversity of the rust pathogen at the Kitale and Kakamega sites given the observation that more differential cultivars were susceptible at these two sites, which was expected because they are located at a higher altitude than the Homabay and Arusha sites. Most of the Andean differential cultivars were susceptible to rust at all four sites with the exception of 'PI 260418', which was resistant at all sites. Andean beans, 'Redlands Pioneer' and 'PC 50', were resistant at two and one of the sites, respectively (Table 2). Most of the Mesoamerican differential cultivars were resistant at three of the four sites with the exception of 'GN 1140', which was susceptible at all four sites, and
'Aurora', which was susceptible at Kakamega and Kitale. These results implied that the race structure of the rust pathogen prevalent at these four locations was Andean composed of races that are virulent only or mostly on common beans belonging to the Andean gene pool (Pastor-Corrales and Aime, 2004). Based on the reaction of the differential cultivars to rust at the sites, the bean rust races were determined to be: 21-1, 29-1, 31-3, and 31-3 at Arusha, Homabay, Kakamega, and Kitale sites, respectively (Table 2) (Steadman et al., 2002). Similarly, rust severity was highest in

the higher altitude Kakamega and Kitale sites followed by Arusha and Homabay. The virulence spectrum of the races of the rust pathogen at the high altitude sites was broader compared with the lower altitude sites as illustrated by the reaction of 'Aurora' and 'Redlands Pioneer', which were rust-susceptible only at the high altitude site (Table 2).

The genotypes used as checks, HS1, HT1, HT2, 'PV698', and 'PV712', were rustresistant at all sites. The observed overall susceptibility of 'Early Gallatin' $(U r-4)$ at four locations in East Africa suggests that the

Table 2. Characteristics of 12 bean differential cultivars and reaction to common bean rust at Arusha, Homabay, Kakamega, and Kitale field sites in East Africa and implied virulence diversity of the pathogen at contrasting field sites in the region.

\begin{tabular}{|c|c|c|c|c|c|c|c|}
\hline \multirow{2}{*}{$\begin{array}{l}\text { Differential } \\
\text { cultivar }\end{array}$} & \multirow{2}{*}{$\begin{array}{l}\text { Rust resistance } \\
\text { gene }^{\mathrm{z}}\end{array}$} & \multirow{2}{*}{$\begin{array}{l}\text { Gene } \\
\text { pool }^{y}\end{array}$} & \multirow{2}{*}{$\begin{array}{l}\text { Binary } \\
\text { value }^{\mathrm{x}}\end{array}$} & \multicolumn{4}{|c|}{ Reaction to rust by site ${ }^{\mathrm{w}, \mathrm{v}}$} \\
\hline & & & & Arusha & Homabay & Kakamega & Kitale \\
\hline Early Gallatin & $U r-4$ & $\mathrm{~A} / \mathrm{MA}$ & 1 & $\mathrm{~S}$ & $\mathrm{~S}$ & $\mathrm{~S}$ & $\mathrm{~S}$ \\
\hline Redlands Pioneer & $U r-13$ & A & 2 & $\mathrm{R}$ & $\mathrm{R}$ & $\mathrm{S}$ & $\mathrm{S}$ \\
\hline Montcalm & Unknown & A & 4 & $\mathrm{~S}$ & $\mathrm{~S}$ & $\mathrm{~S}$ & $\mathrm{~S}$ \\
\hline P.C. 50 & $U r-9$ and $U r-12$ & A & 8 & $\mathrm{R}$ & $\mathrm{S}$ & $\mathrm{S}$ & $\mathrm{S}$ \\
\hline Golden Gate Wax & $U r-6$ & $\mathrm{~A} / \mathrm{MA}$ & 16 & $\mathrm{~S}$ & $\mathrm{~S}$ & $\mathrm{~S}$ & $\mathrm{~S}$ \\
\hline PI 260418 & $U r-P$ (unknown) & A & 32 & $\mathrm{R}$ & $\mathrm{R}$ & $\mathrm{R}$ & $\mathrm{R}$ \\
\hline Great Northern 1140 & $U r-7$ & MA & 1 & $\mathrm{~S}$ & $\mathrm{~S}$ & $\mathrm{~S}$ & $\mathrm{~S}$ \\
\hline Aurora & $U r-3$ & MA & 2 & $\mathrm{R}$ & $\mathrm{R}$ & $\mathrm{S}$ & $\mathrm{S}$ \\
\hline Mexico 309 & $U r-5$ & MA & 4 & $\mathrm{R}$ & $\mathrm{R}$ & $\mathrm{R}$ & $\mathrm{R}$ \\
\hline Mexico 235 & $U r-3+$ & MA & 8 & $\mathrm{R}$ & $\mathrm{R}$ & $\mathrm{R}$ & $\mathrm{R}$ \\
\hline $\mathrm{CNC}$ & Unknown & MA & 16 & $\mathrm{R}$ & $\mathrm{R}$ & $\mathrm{R}$ & $\mathrm{R}$ \\
\hline PI 181996 & $U r-11$ & MA & 32 & $\mathrm{R}$ & $\mathrm{R}$ & $\mathrm{R}$ & $\mathrm{R}$ \\
\hline \multicolumn{2}{|c|}{ Rust race } & & & $21-1$ & $29-1$ & $31-3$ & $31-3$ \\
\hline
\end{tabular}

${ }^{2}$ Differential cultivar with Unknown in the rust resistance gene column has an unidentified rust gene. ${ }^{\mathrm{y}} \mathrm{A}=$ differential cultivars from the Andean gene pool; $\mathrm{MA}=$ those from the Middle American gene pool; $\mathrm{A} / \mathrm{MA}=$ those differential cultivars occurring in both gene pools.

${ }^{x}$ Binary value refers to the value that rust-resistance genes in the differential cultivars have been assigned based on the spectrum of virulent races of the bean rust pathogen they are able to control. The higher values are assigned to those genes that confer resistance to a wider spectrum of the rust races.

${ }^{\mathrm{w}} \mathrm{S}$ and $\mathrm{R}=$ susceptible and resistant reactions, respectively. In the case of resistant reaction, rust symptoms are absent.

${ }^{\vee}$ Based on susceptible reaction of the differential cultivars, the virulence diversity of the common bean rust at the sites was in the order of Arusha $<$ Homabay $<$ Kakamega $=$ Kitale.

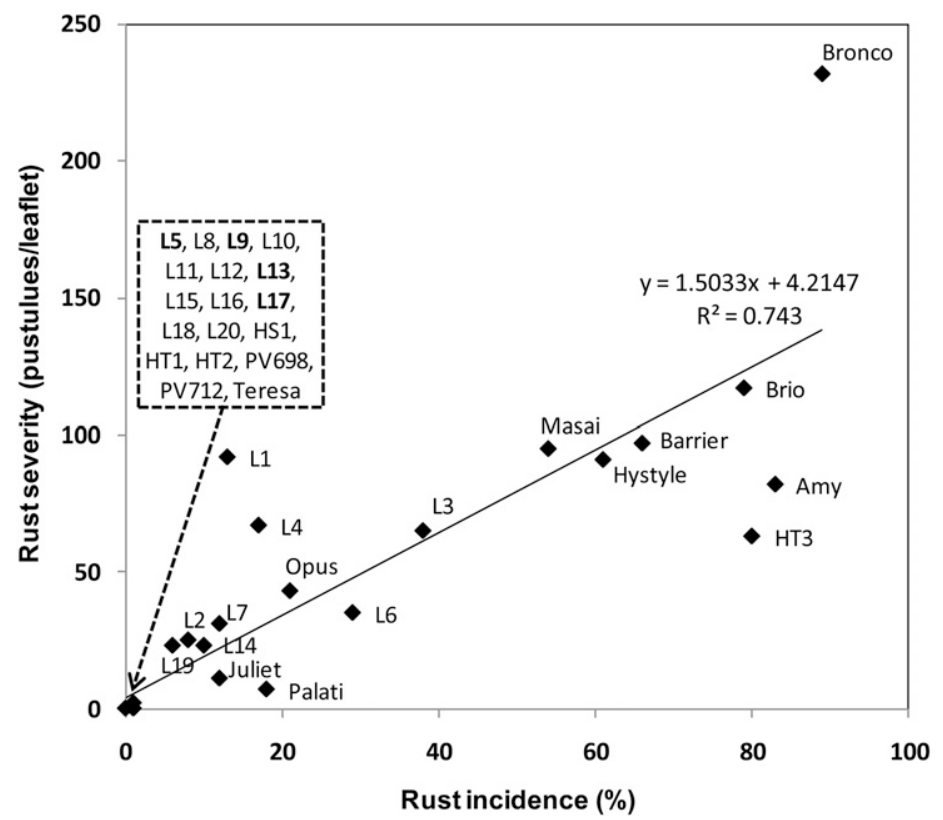

Fig. 2. Rust incidence (rust infected plants) and severity on 20 snap bean breeding lines (L1-L20) and 16 control lines evaluated in 2010. The data points are lines means over four field sites: Arusha, Homabay, Kakamega, and Kitale. HT1, HT2, HT3, HS1, Amy, Bronco Masai, PV712, and Teresa were the parents. 
Table 3. Pod yield of 36 snap bean lines evaluated in 2010 at four field sites in East Africa. ${ }^{\mathrm{z}}$

\begin{tabular}{|c|c|c|c|c|}
\hline \multirow[b]{2}{*}{ Line } & \multicolumn{4}{|c|}{ Pods/plant ${ }^{\mathrm{y}}$} \\
\hline & Arusha & Homabay & Kakamega & Kitale \\
\hline$\overline{\mathrm{L} 1}$ & $15.0 \mathrm{a}$ & $26.8 \mathrm{ab}$ & $16.2 \mathrm{a}$ & $16.8 \mathrm{a}$ \\
\hline L2 & $10.5 \mathrm{a}$ & $12.7 \mathrm{~b}$ & $15.3 \mathrm{a}$ & $15.7 \mathrm{~b}$ \\
\hline L3 & $8.7 \mathrm{a}$ & $21.1 \mathrm{ab}$ & $18.6 \mathrm{a}$ & $15.9 \mathrm{~b}$ \\
\hline L4 & $12.5 \mathrm{a}$ & $20.8 \mathrm{ab}$ & $16.8 \mathrm{a}$ & $16.7 \mathrm{ab}$ \\
\hline L5 & $9.3 \mathrm{a}$ & $20.7 \mathrm{ab}$ & $17.7 \mathrm{a}$ & $17.0 \mathrm{ab}$ \\
\hline L6 & $9.7 \mathrm{a}$ & $24.3 \mathrm{ab}$ & $19.5 \mathrm{a}$ & $17.0 \mathrm{ab}$ \\
\hline L7 & $9.9 \mathrm{a}$ & $20.0 \mathrm{ab}$ & $19.3 \mathrm{a}$ & $13.3 \mathrm{~b}$ \\
\hline L8 & $7.0 \mathrm{a}$ & $18.9 \mathrm{ab}$ & $15.1 \mathrm{a}$ & $17.3 \mathrm{ab}$ \\
\hline L9 & $14.2 \mathrm{a}$ & 28.7 a & $15.6 \mathrm{a}$ & $21.4 \mathrm{ab}$ \\
\hline L10 & $11.0 \mathrm{a}$ & $20.1 \mathrm{ab}$ & $19.4 \mathrm{a}$ & $14.1 \mathrm{~b}$ \\
\hline L11 & $9.4 \mathrm{a}$ & $21.0 \mathrm{ab}$ & $16.0 \mathrm{a}$ & $15.5 \mathrm{~b}$ \\
\hline L12 & $11.8 \mathrm{a}$ & $19.6 \mathrm{ab}$ & $15.8 \mathrm{a}$ & $16.9 \mathrm{ab}$ \\
\hline L13 & $12.2 \mathrm{a}$ & $24.5 \mathrm{ab}$ & 17.7 a & $16.6 \mathrm{ab}$ \\
\hline L14 & $19.9 \mathrm{a}$ & $21.1 \mathrm{ab}$ & $19.3 \mathrm{a}$ & $18.0 \mathrm{ab}$ \\
\hline L15 & $15.7 \mathrm{a}$ & $22.7 \mathrm{ab}$ & $15.6 \mathrm{a}$ & $19.6 \mathrm{ab}$ \\
\hline L16 & $12.2 \mathrm{a}$ & $23.9 \mathrm{ab}$ & $16.6 \mathrm{a}$ & $15.4 \mathrm{~b}$ \\
\hline L17 & $22.2 \mathrm{a}$ & $22.5 \mathrm{ab}$ & $20.2 \mathrm{a}$ & $21.8 \mathrm{ab}$ \\
\hline L18 & $14.2 \mathrm{a}$ & $21.1 \mathrm{ab}$ & $17.6 \mathrm{a}$ & $18.2 \mathrm{ab}$ \\
\hline L19 & $21.4 \mathrm{a}$ & $27.7 \mathrm{a}$ & $17.1 \mathrm{a}$ & $17.4 \mathrm{ab}$ \\
\hline L20 & $15.9 \mathrm{a}$ & $25.1 \mathrm{ab}$ & $15.5 \mathrm{a}$ & $17.5 \mathrm{ab}$ \\
\hline HT3 & $8.4 \mathrm{a}$ & $20.0 \mathrm{ab}$ & $19.1 \mathrm{a}$ & $13.6 \mathrm{~b}$ \\
\hline HS1 & $6.2 \mathrm{a}$ & $24.4 \mathrm{ab}$ & $17.7 \mathrm{a}$ & $18.9 \mathrm{ab}$ \\
\hline HT1 & $9.6 \mathrm{a}$ & $19.9 \mathrm{ab}$ & $17.5 \mathrm{a}$ & $18.1 \mathrm{ab}$ \\
\hline HT2 & $16.8 \mathrm{a}$ & $27.2 \mathrm{a}$ & $17.2 \mathrm{a}$ & $16.9 \mathrm{ab}$ \\
\hline OPUS & $12.3 \mathrm{a}$ & $25.7 \mathrm{ab}$ & $21.2 \mathrm{a}$ & $14.3 \mathrm{~b}$ \\
\hline Palati & $15.0 \mathrm{a}$ & $24.5 \mathrm{ab}$ & $19.5 \mathrm{a}$ & $13.2 \mathrm{~b}$ \\
\hline Hystyle & $11.7 \mathrm{a}$ & $22.2 \mathrm{ab}$ & $19.5 \mathrm{a}$ & $12.8 \mathrm{~b}$ \\
\hline Barrier & $8.2 \mathrm{a}$ & $30.6 \mathrm{a}$ & $23.1 \mathrm{a}$ & $11.1 \mathrm{~b}$ \\
\hline PV698 & $16.1 \mathrm{a}$ & $26.0 \mathrm{ab}$ & $14.3 \mathrm{a}$ & $23.5 \mathrm{ab}$ \\
\hline Amy & $19.0 \mathrm{a}$ & $19.4 \mathrm{ab}$ & $13.5 \mathrm{a}$ & $21.8 \mathrm{ab}$ \\
\hline Juliet & $13.9 \mathrm{a}$ & $23.6 \mathrm{ab}$ & $13.5 \mathrm{a}$ & $18.5 \mathrm{ab}$ \\
\hline Masai & $20.0 \mathrm{a}$ & $19.0 \mathrm{ab}$ & $15.5 \mathrm{a}$ & $28.3 \mathrm{a}$ \\
\hline Brio & $8.6 \mathrm{a}$ & $21.5 \mathrm{ab}$ & $16.6 \mathrm{a}$ & $15.9 \mathrm{~b}$ \\
\hline PV712 & $13.6 \mathrm{a}$ & $18.2 \mathrm{ab}$ & $15.2 \mathrm{a}$ & $15.7 \mathrm{~b}$ \\
\hline Teresa & $18.8 \mathrm{a}$ & $23.5 \mathrm{ab}$ & $14.7 \mathrm{a}$ & $21.1 \mathrm{ab}$ \\
\hline Bronco & $14.1 \mathrm{a}$ & $19.6 \mathrm{ab}$ & $20.2 \mathrm{a}$ & $16.9 \mathrm{ab}$ \\
\hline Mean & $13.2 \mathrm{C}$ & $22.5 \mathrm{~A}$ & $17.3 \mathrm{~B}$ & $17.3 \mathrm{~B}$ \\
\hline
\end{tabular}

${ }^{\mathrm{z} L 1-L 20}$ were rust-resistant/heat-tolerant breeding lines targeted for selection at the field sites.

${ }^{\mathrm{y}}$ Within a site/column, line means followed by the same letter are not significantly different according to Tukey's test. The last row on the table shows mean site differences in pod yield for all the lines tested. The lines L5, L9, L13, and L17 that are highlighted in bold are the rust-resistant breeding lines selected during the evaluation trials across the four East Africa sites.

rust resistance of the snap bean lines is derived from $U r-11$, which had previously also been shown to effectively confer rust resistance at numerous sites in East Africa (Wasonga et al., 2010). 'Teresa' (which has $U r-5$ ) was not completely resistant, because a few rust pustules were observed on $4 \%$ of the plants at Kakamega. 'Palati', which also has the Ur-5 gene, was rust-infected but at a low frequency with rust incidences of $10 \%, 11 \%$, and $34 \%$ in Arusha, Homabay, and Kakamega, respectively. The cultivars Amy, Barrier, Brio, Bronco, Hystyle, and Masai were rustsusceptible at all four East African sites with 'Bronco' having the highest density of leaf pustules (Fig. 2).

Twelve of the 20 snap bean breeding lines evaluated were resistant to rust at all sites in East Africa (Fig. 2). The resistance of the 12 breeding lines was attributed to the the $U r-11$ gene as inferred from the reaction of the differential cultivars listed previously. The

Table 4. Mean values and rankings of plant seed weight and pod seed number in 36 snap bean lines grown at a hot field site in Juana Diaz, Puerto Rico, during the summer of $2010,35 / 23{ }^{\circ} \mathrm{C}$ (day/night), and in a greenhouse under high temperature conditions, $28 / 23{ }^{\circ} \mathrm{C}$ (day/night). ${ }^{\mathrm{z}}$

\begin{tabular}{|c|c|c|c|c|c|c|c|c|}
\hline \multirow[b]{3}{*}{$\operatorname{Line}^{\mathrm{y}}$} & \multicolumn{4}{|c|}{ Puerto Rico } & \multicolumn{4}{|c|}{ Greenhouse } \\
\hline & \multicolumn{2}{|c|}{ Seed wt/plant (g) } & \multicolumn{2}{|c|}{ Seeds/pod } & \multicolumn{2}{|c|}{ Seed wt/plant (g) } & \multicolumn{2}{|c|}{ Seeds/Pod } \\
\hline & Value & Rank & Value & $\overline{\text { Rank }}$ & Value & Rank & Value & $\overline{\text { Rank }}$ \\
\hline$\overline{\mathrm{L} 1}$ & $2.6 \mathrm{e}$ & 21 & $1.6 \mathrm{a}$ & 22 & $8.5 \mathrm{bc}$ & 5 & $3.6 \mathrm{a}-\mathrm{g}$ & 11 \\
\hline L2 & $6.1 \mathrm{c}-\mathrm{e}$ & 16 & $1.5 \mathrm{a}$ & 26 & $3.8 \mathrm{de}$ & 34 & $1.8 \mathrm{~lm}$ & 34 \\
\hline L3 & $7.1 \mathrm{c}-\mathrm{e}$ & 15 & $2.5 \mathrm{a}$ & 6 & $8.4 \mathrm{bc}$ & 6 & $3.8 \mathrm{a}-\mathrm{d}$ & 5 \\
\hline L4 & $12.8 \mathrm{~b}-\mathrm{e}$ & 6 & $2.1 \mathrm{a}$ & 14 & $14.9 \mathrm{a}$ & 1 & $3.6 \mathrm{a}-\mathrm{f}$ & 10 \\
\hline L5 & $1.8 \mathrm{e}$ & 24 & $1.4 \mathrm{a}$ & 30 & $8.7 \mathrm{~b}$ & 4 & $3.7 \mathrm{a}-\mathrm{e}$ & 8 \\
\hline L6 & $8.1 \mathrm{c}-\mathrm{e}$ & 13 & $2.5 \mathrm{a}$ & 5 & $12.1 \mathrm{a}$ & 2 & $3.5 \mathrm{a}-\mathrm{h}$ & 13 \\
\hline L7 & $10.2 \mathrm{~b}-\mathrm{e}$ & 8 & $3.0 \mathrm{a}$ & 2 & $6.4 \mathrm{~b}-\mathrm{e}$ & 18 & $3.2 \mathrm{c}-\mathrm{i}$ & 16 \\
\hline L8 & $4.5 \mathrm{c}-\mathrm{e}$ & 18 & $2.4 \mathrm{a}$ & 12 & $5.5 \mathrm{~b}-\mathrm{e}$ & 26 & $2.6 \mathrm{f}-1$ & 28 \\
\hline L9 & $4.9 \mathrm{c}-\mathrm{e}$ & 17 & $1.4 \mathrm{a}$ & 28 & $7.2 \mathrm{~b}-\mathrm{d}$ & 11 & $3.0 \mathrm{c}-\mathrm{i}$ & 19 \\
\hline L10 & $1.9 \mathrm{e}$ & 23 & $1.7 \mathrm{a}$ & 18 & $6.4 \mathrm{~b}-\mathrm{e}$ & 16 & $2.6 \mathrm{f}-1$ & 27 \\
\hline L11 & $3.5 \mathrm{de}$ & 19 & $1.5 \mathrm{a}$ & 25 & $6.2 \mathrm{~b}-\mathrm{e}$ & 22 & $3.0 \mathrm{c}-\mathrm{i}$ & 20 \\
\hline L12 & $14.6 \mathrm{~b}-\mathrm{e}$ & 5 & $2.4 \mathrm{a}$ & 11 & $7.1 \mathrm{~b}-\mathrm{d}$ & 12 & $2.9 \mathrm{c}-\mathrm{j}$ & 22 \\
\hline L13 & $0.2 \mathrm{e}$ & 33 & $1.9 \mathrm{a}$ & 15 & $4.5 \mathrm{c}-\mathrm{e}$ & 30 & $4.3 \mathrm{ab}$ & 2 \\
\hline L14 & $9.1 \mathrm{~b}-\mathrm{e}$ & 10 & $1.5 \mathrm{a}$ & 24 & $7.4 \mathrm{~b}-\mathrm{d}$ & 7 & $4.2 \mathrm{ab}$ & 3 \\
\hline L15 & $9.0 \mathrm{~b}-\mathrm{e}$ & 11 & $1.4 \mathrm{a}$ & 29 & $6.4 \mathrm{~b}-\mathrm{e}$ & 17 & $2.7 \mathrm{e}-1$ & 26 \\
\hline L16 & $21.7 \mathrm{~b}-\mathrm{c}$ & 4 & $1.6 \mathrm{a}$ & 19 & $5.9 \mathrm{~b}-\mathrm{e}$ & 24 & $3.2 \mathrm{c}-\mathrm{i}$ & 17 \\
\hline L17 & $0.2 \mathrm{e}$ & 32 & $1.6 \mathrm{a}$ & 21 & $6.3 \mathrm{~b}-\mathrm{e}$ & 19 & $2.8 \mathrm{~d}-\mathrm{k}$ & 23 \\
\hline L18 & $2.4 \mathrm{e}$ & 22 & $1.6 \mathrm{a}$ & 23 & $4.9 \mathrm{~b}-\mathrm{e}$ & 29 & $3.7 \mathrm{a}-\mathrm{d}$ & 7 \\
\hline L19 & $1.1 \mathrm{e}$ & 28 & $1.4 \mathrm{a}$ & 27 & $5.9 \mathrm{~b}-\mathrm{e}$ & 23 & $2.8 \mathrm{~d}-\mathrm{k}$ & 24 \\
\hline L20 & $7.3 \mathrm{c}-\mathrm{e}$ & 14 & $1.7 \mathrm{a}$ & 16 & $7.3 \mathrm{~b}-\mathrm{d}$ & 10 & $3.5 \mathrm{a}-\mathrm{h}$ & 12 \\
\hline HT3 & $32.9 \mathrm{a}$ & 1 & $2.4 \mathrm{a}$ & 10 & $8.9 \mathrm{~b}$ & 3 & $4.4 \mathrm{a}$ & 1 \\
\hline HS1 & $11.6 \mathrm{~b}-\mathrm{e}$ & 7 & $1.7 \mathrm{a}$ & 17 & $6.3 \mathrm{~b}-\mathrm{e}$ & 20 & $3.6 \mathrm{a}-\mathrm{f}$ & 9 \\
\hline HT1 & $8.7 \mathrm{~b}-\mathrm{e}$ & 12 & $3.2 \mathrm{a}$ & 1 & 7. $4 \mathrm{~b}-\mathrm{d}$ & 8 & $3.2 \mathrm{c}-\mathrm{i}$ & 15 \\
\hline HT2 & $1.4 \mathrm{e}$ & 26 & $1.0 \mathrm{a}$ & 32 & $5.5 \mathrm{~b}-\mathrm{e}$ & 25 & $1.9 \mathrm{k}-\mathrm{m}$ & 33 \\
\hline Opus & $1.3 \mathrm{e}$ & 27 & $1.0 \mathrm{a}$ & 33 & $7.3 \mathrm{~b}-\mathrm{d}$ & 9 & $3.4 \mathrm{~b}-\mathrm{i}$ & 14 \\
\hline Palati & $2.9 \mathrm{e}$ & 20 & $2.2 \mathrm{a}$ & 13 & $3.7 \mathrm{de}$ & 35 & $1.3 \mathrm{~m}$ & 36 \\
\hline Hystyle & $0.8 \mathrm{e}$ & 30 & $2.6 \mathrm{a}$ & 3 & $6.3 \mathrm{~b}-\mathrm{e}$ & 21 & $2.5 \mathrm{~h}-1$ & 30 \\
\hline Barrier & $0.9 \mathrm{e}$ & 29 & $1.3 \mathrm{a}$ & 31 & $6.4 \mathrm{~b}-\mathrm{e}$ & 15 & $2.7 \mathrm{e}-1$ & 25 \\
\hline PV698 & $0.0 \mathrm{e}$ & 35 & $1.0 \mathrm{a}$ & 34 & $2.6 \mathrm{e}$ & 36 & $2.0 \mathrm{j}-\mathrm{m}$ & 32 \\
\hline Amy & $26.5 \mathrm{ab}$ & 2 & $2.5 \mathrm{a}$ & 8 & $7.0 \mathrm{~b}-\mathrm{d}$ & 13 & $3.7 \mathrm{a}-\mathrm{d}$ & 6 \\
\hline Juliet & $0.2 \mathrm{e}$ & 31 & $2.5 \mathrm{a}$ & 9 & $5.0 \mathrm{~b}-\mathrm{e}$ & 27 & $2.9 \mathrm{c}-\mathrm{j}$ & 21 \\
\hline Masai & $0.0 \mathrm{e}$ & 34 & $1.0 \mathrm{a}$ & 35 & $4.0 \mathrm{de}$ & 32 & $3.1 \mathrm{c}-\mathrm{i}$ & 18 \\
\hline Brio & $22.6 \mathrm{a}-\mathrm{c}$ & 3 & $2.5 \mathrm{a}$ & 7 & $6.9 \mathrm{~b}-\mathrm{d}$ & 14 & $3.9 \mathrm{a}-\mathrm{c}$ & 4 \\
\hline PV712 & $0.0 \mathrm{e}$ & 36 & - & - & $3.8 \mathrm{de}$ & 33 & $1.7 \mathrm{~lm}$ & 35 \\
\hline Teresa & $9.2 \mathrm{~b}-\mathrm{e}$ & 9 & $1.6 \mathrm{a}$ & 20 & $4.2 \mathrm{de}$ & 31 & $2.4 \mathrm{i}-1$ & 31 \\
\hline Bronco & $1.8 \mathrm{e}$ & 25 & $2.6 \mathrm{a}$ & 4 & $5.0 \mathrm{~b}-\mathrm{e}$ & 28 & 2. $6 \mathrm{~g}-1$ & 29 \\
\hline
\end{tabular}

${ }^{\mathrm{z}}$ Within a column, values followed by the same letter are not significantly different according to Tukey's test.

${ }^{\mathrm{y}}$ The lines L1-L20 are breeding lines targeted for selection for rust resistance ( $U r-4$ and $U r$ - 11 rust genes) and heat tolerance.

breeding lines L1, L3, L4, L6, L7, L14, and L19 were heterozygous for the $U r-11$ gene (Fig. 2). The 12 rust-resistant breeding lines were therefore subjected to further selection based on yield and pod quality.

\section{Yield under field conditions}

The top five yielding lines at the four sites were L17 followed by L19, 'Masai', L9, and 'PV698' (Table 3). 'Masai', which was included as a heat-sensitive and rust-susceptible control, had lower yield in Homabay (which was the hottest of the sites) compared with its yield at the cool, high-altitude site in Kitale and was consistent with its performance at these two sites in 2009 (Wasonga et al., 2010). From the 12 rust-resistant entries, L5, L9, L13, and L17 were selected as the most promising on the basis of high yields, high pod quality, and upright bush plant phenotype (Table 3).

L17 had a consistently high pod load in Arusha, where it was the highest yielding line. In Kakamega and Kitale, L17 was among the top three highest yielders and in Homabay it had a mean yield equal to the overall site mean yield (Table 3). L17 has high-quality pods - straight, fleshy, small-sieve sized pods and an upright bush plant growth habit and small- to medium-sized leaves that makes its canopy relatively open. As a selection from the HT1 and 'Teresa' cross (Table 1), L17 is also fixed or segregating for the $U r-5$ rust-resistance gene based on results from previous (Wasonga et al., 2010) and present field studies (Fig. 1). $U r-5$ is the most important rust-resistance gene after $U r-11$ for East Africa. Further refinement of L17 will be needed to ensure that it is fixed for $U r-5$ and $U r-11$ before release as a cultivar with broad and durable rust resistance.

L13 is a rust-resistant selection derived from a cross of HT1 and 'Masai' (Table 1). It has straight fleshy pods, which are longer than those of 'Masai', and an upright growth habit. The line had good pod set and yield equivalent to the mean site yields for Arusha, Kakamega, and Kitale (Table 3). Its pod yield at Homabay was higher than that of the grand mean for the site and also higher than the mean pod yields of both its parents (Table 3). The yield of L13 at the higher temperature Homabay site showed that, in addition to being rust-resistant, this selection has 


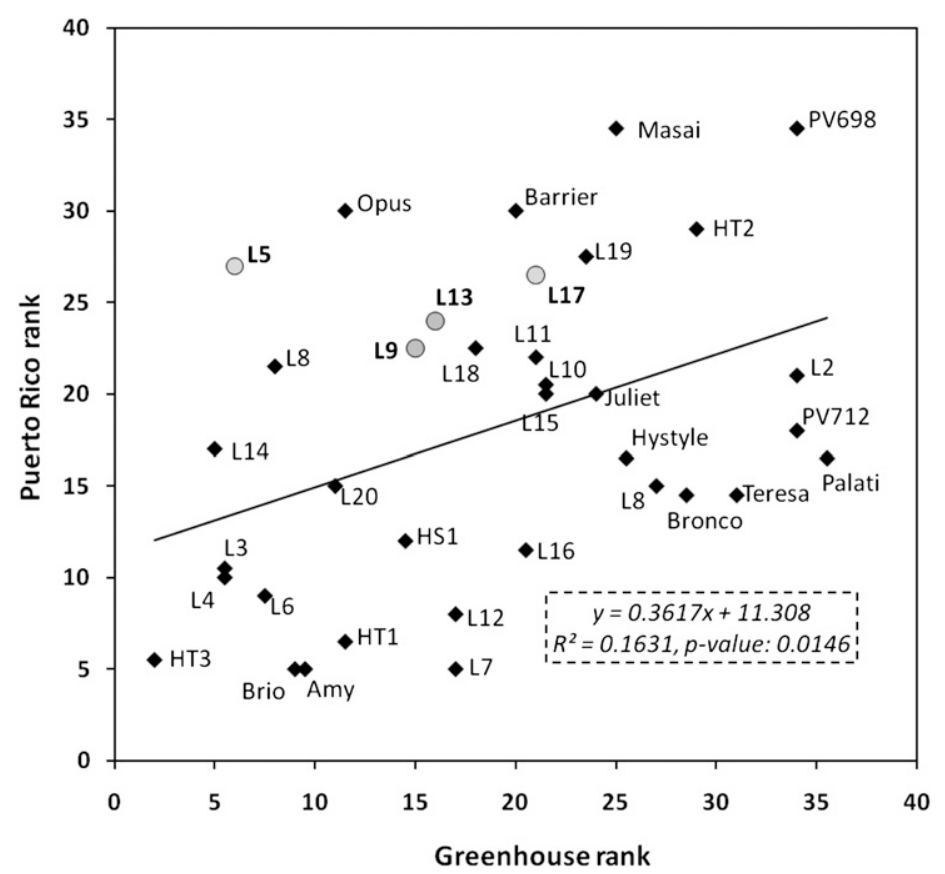

Fig. 3. Correlation of greenhouse and Puerto Rico mean line rankings for seed weight per plant and number of seeds per pod generated from 2010 trials. The data points are means for eight observations.

considerable level of heat tolerance compared with 'Masai', one of the parents from which it was derived, and may therefore have better adaptation and productivity in warmer, lower altitude sites. The high pod set trait derived from 'Masai' was verified at the cooler higher altitude sites such as Kitale (Table 3).

L9 is a rust-resistant selection derived from crossing HT1 with 'PV712' (Table 1). It has an upright bush habit with straight, fleshy, small-sieve pods. Its mean pod yield at each of the four sites was significantly higher than the mean of each of its parents, HT1and PV712. Line L9 was ranked best among the 12 rust-resistant breeding lines and was the second best line among the 36 snap bean lines tested at the Homabay site (Table 3). The high yield of L9 at Homabay shows that it has good levels of heat tolerance and that it is more adapted to this low altitude site than its parents and the other lines tested.

\section{Comparison of response to high- temperature conditions in the greenhouse and field}

Response of the breeding lines to hightemperature conditions was evaluated using data from the greenhouse and field site in Juana Diaz, Puerto Rico. Two yield components: seed weight per plant and seeds per pod, which are more indicative of heat tolerance, were measured at these two environments (Table 4). In the evaluation under the two environments, the entries were compared for their relative ranking for the two yield components. Spearman's rank correlation calculated for the 36 lines between the two sites were $R=$ 0.48 with a $P \leq 0.005$ for mean seed weight per plant and $P \leq 0.01$ for seeds per pod. These results demonstrate the ability to select for heat tolerance traits in a controlled-temperature environment that have representative rankings in a field testing environment The rank correlations implied that line performance in the controlled greenhouse environment $\left(32 / 27^{\circ} \mathrm{C}\right)$ was indicative of performance in the hightemperature field site in Puerto Rico in response to heat stress. The best lines at these two environments could therefore be considered to be more heat-tolerant relative to the other lines evaluated. In this regard, breeding line HT3 could be considered the most heattolerant, whereas 'PV698' and 'Masai' could be considered the most heat-sensitive based on the results from the 2010 trial (Fig. 3). The observed response of these lines under the greenhouse and field environments characterized by high temperatures is in part consistent with that made during the 2009 season (Wasonga et al., 2010) in which 'PV698' and 'Masai' were found to be heat-sensitive based on their responses at the high-temperature sites of Homabay and Puerto Rico. The breeding selections L5, L9, and L13 could be considered to have heat tolerance for smallsieve selections given their overall rankings among the 36 lines and specifically in relation to their parents: 'Bronco', 'PV698', and 'Masai', which ranked lower on average across the two environments.

\section{Conclusions}

Four small-sieve snap bean entries that were developed and combine the $U r-4$ and $U r-11$ rust-resistance genes and tolerance to high temperature stress (L5, L9, L13, and L17) demonstrate that these traits can be effectively combined into desired market types for the development of cultivars with better adaptation to the growing constraints. This research demonstrated that small-sieve snap beans with high yields and quality of pods can be developed and selected and would benefit significantly from broadspectrum resistance to rust provided by the combination of $U r-4$ and $U r-11$ in a high-temperature tolerant genotype. Cultivars combining the $U r-4$ and $U r-11$ resistance genes would reduce dependence on fungicides in the control of rust, resulting in reduced production costs and increased crop quality. The high-temperature tolerance trait in the cultivars would enable increased production of high-quality snap beans in areas and seasons characterized by higher than optimal temperatures that are also subject to climate change.

\section{Literature Cited}

Araya, C.M., A.T. Alleyne, J.R. Steadman, K.M. Eskridge, and D.P. Coyne. 2004. Phenotypic and genotypic characterization of Uromyces appendiculatus from Phaseolus vulgaris in the Americas. Plant Dis. 88:830-836.

Boodley, J.W. and R. Sheldrake. 1972. Cornell peatlite mixes for commercial plant growing. Cornell Info. Bull. 43:1-8.

CBI. 2006. The fresh fruit and vegetables market in the EU. CBI Market Survey. CBI, Rotterdam, The Netherlands.

Centro Internacional de Agricultura Tropical. 2006. CIAT in Africa: Snap beans for income generation by small farmers in east Africa. $30 \mathrm{Dec}$. 2011. <http://www.CIAT.CGIAR.org.africa/pdf/ highlight31.pdf $>$.

Challinor, A.T., T. Wheeler, C. Garforth, P. Craufurd, and A. Kassam. 2007. Assessing the vulnerability of food crop systems in Africa to climate change. Clim. Change 83:381-399.

Christensen, J.H., B.C. Hewitson, A. Busuioc, A. Chen, X. Gao, R. Jones, W.T. Kwon, R. Laprise, V. Magana, L. Mearns, C. Menendez, J. Raisaenes, A. Rinke, R.K. Kolli, A. Starr, and P. Whetton. 2007. Regional climate projections. In: Solomon S., D. Qin, M. Manning, Z. Chen, M. Marquis, K.B. Averyt, M. Tignor, and H.L. Miller (eds.). Climate change 2007: The physical science basis. Contribution of Working Group I to the Fourth Assessment Report of the Intergovernmental Panel on Climate Change. Cambridge University Press, Cambridge, UK.

Cline, W. 2007. Global warming and agriculture: impact estimates by country. Peterson Institute, Washington, DC.

Hulme, M., R. Doherty, T. Ngara, M. New, and D. Lister. 2001. African climate change: 19002100. Clim. Res. 17:145-168.

Kimani, P.M., H. Assefa, G. Rakotomalala, and A. Rabakoarihanta. 2002. Research on bean rust in East and Central Africa: Status and future directions. Annual Report BIC 45:134-135.

King'uyu, S.M., L.A. Ogallo, and E.K. Anyamba. 2000. Recent trends of minimum and maximum surface temperatures over East Africa. J. Clim. 13:2876-2886.

Kinyuru, J.N., K.P. Kahenya, M. Muchui, and H. Mungai. 2011. Influence of post-harvest handling on the quality of snap bean (Phaseolus vulgaris L.). J. Agr. Food Technol. 1:43-46.

Liebenberg, M.M. 2003. Breeding for resistance to rust of dry bean (Phaseolus vulgaris) in South Africa. PhD thesis, University of the Free State, Bloemfontein, South Africa.

Liebenberg, M.M., C.M.S. Mienie, and Z.A. Pretorius. 2006. The occurrence of rust resistance gene $U r-13$ in common bean cultivars and lines. Euphytica 150:365-386. 
Markell, S.G., M.A. Pastor-Corrales, J.G. Jordahl, R.S. Lamppa, F.M. Mathew, J.M. Osorno, and R.S. Goswami. 2009. Virulence of Uromyces appendiculatus to the resistance gene $U r-3$ identified in North Dakota. Annu. Rep. Bean Improv. Coop. 52:82-83.

Muchui, M.N., A. Ndegwa, S. Wachiuri, B. Muthama, and J. Kimamira. 2008. Postharvest evaluation of introduced French bean (Phaseolus vulgaris L.) varieties. Afr. J. Hort. Sci. 1:116120.

Okello, J.J. and D. Roy. 2007. Food safety requirements in African green bean exports and their impact on small farmers. IFPRI Discussion Paper 00737. International Food Policy Research Institute, Washington, DC.

Pastor-Corrales, M.A. 2006. Diversity of the rust pathogen and common bean guides gene deployment for development of bean cultivars with durable rust resistance. Annu. Rep. Bean Improv. Coop. 49:51-52.
Pastor-Corrales, M.A. and M.C. Aime. 2004. Differential cultivars and molecular markers segregate isolates of Uromyces appendiculatus into two distinct groups that correspond to the gene pools of their common bean hosts. Phytopathology 94:82.

Porch, T.G. and M. Jahn. 2001. Effects of hightemperature stress on microsporogenesis in heatsensitive and heat-tolerant genotypes of Phaseolus vulgaris. Plant Cell Environ. 24:723-731.

Rainey, K.M. and P.D. Griffiths. 2005. Inheritance of heat tolerance during reproductive development in snap bean (Phaseolus vulgaris L.). J. Amer. Soc. Hort. Sci. 130:700-706.

Stavely, J.R. and M.A. Pastor-Corrales. 1989. Rust, p. 159-194. In: Schwartz, H.F. and M.A. PastorCorrales (eds.). Bean production problems in the Tropics. CIAT, Cali, Columbia.

Steadman, J.R., M.A. Pastor-Corrales, and J.S Beaver. 2002. An overview of the 3rd bean. In: Tubiello, F.J., M.H. Schmidhuber, P.G.
Neofotis, S. Park, E. Fernandes, and D. Thapa (eds.). 2008 climate change response strategies for agriculture: Challenges and opportunities for the 21st century. World Bank, Agriculture and Rural Development Discussion Paper 42.

Wahid, A., S. Gelani, M. Ashraf, and M.R. Foolad. 2007. Heat tolerance in plants: An overview. Environ. Exp. Bot. 61:199-223.

Wasonga, C.J., M.A. Pastor-Corrales, T.G. Porch, and P.D. Griffiths. 2010. Targeting gene combinations for broad spectrum rust resistance and heat tolerance in snap beans for tropical environments. J. Amer. Soc. Hort. Sci. 135:521-532.

Wortmann, C.S., R.A. Kirkby, C.A. Eledu, and D.J. Allen. 1998. Atlas of common bean (Phaseolus vulgaris L.) production in Africa. CIAT, Cali, Columbia.

Wright, E.M., H.E. Awale, and J.D. Kelly. 2008. Use of TRAP markers to map resistance to a new race of common bean rust in Michigan. Annu. Rep. Bean Improv. Coop. 51:210-211. 